\title{
SEIVA PARA O SALTO CIVILIZATÓRIO: O LUGAR DAS REDES NA BUSCA PELO ANCESTRAL E O COMUNITÁRIO ${ }^{1}$
}

Célio Turino

\begin{abstract}
Resumo
O artigo aborda as conexões sociais como processo de transformação social, busca recuperar o fio da história das culturas comunitárias e ancestrais. Aponta o papel das redes como movimento de aceleração de processos de desenvolvimento humano o que possibilita relações comunitárias sedimentadas. Apresenta a Cultura do Encontro como uma das ferramentas que pode propiciar inteireza ética, estética, econômica e educativa a partir de processos empáticos, realizados no exercício da alteridade, seguindo um mesmo sentido. O comunitário e o ancestral interagem, em diferentes medidas, com os outros Sistemas, e são afetados por esses, como também podem afetar e alterar o funcionamento e a lógica desses Sistemas.
\end{abstract}

Palavras-chave: Conexões Sociais.Transformação social. Redes.

\section{SAP TO THE CIVILIAN HEEL: PLACE OF THE NETWORKS IN THE SEARCH FOR THE COMMUNITY'S ANCESTOR}

\begin{abstract}
The article approaches social connections as a process of social transformation, seeks to recover the thread of the history of community and ancestral cultures. It points to the role of networks as an accelerating movement of human development processes, which enables solidified community relations. It presents the Culture of Encounter as one of the tools that can provide ethical, aesthetic, economic and educational wholeness from empathic processes, performed in the exercise of otherness, following the same meaning. The community and the ancestor interact, to varying degrees, with and are affected by the other Systems, as they may also affect and alter the functioning and logic of these Systems.
\end{abstract}

Keywords: Social Connections. Social Transformation. Networks.

\footnotetext{
${ }^{1}$ Artigo preparado como atividade de final do curso O lugar das Performances: Produção partilhada do conhecimento.

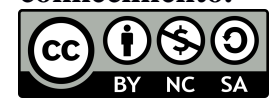




\section{CONTEXTUALIZAÇÃO INICIAL}

Redes há em profusão, o desafio é conectar as redes contemporâneas ao ancestral e o comunitário, recriando sentidos a partir de redes de afetos, desejos e vontades. Cabe estabelecer macrorredes, integrando coletivos de culturas comunitárias com coletivos de inovação tecnológica, artística e confrontação com o Sistema dominante, bem como, conectando essas macrorredes da diversidade com ambientes de reflexão, investigação e pesquisa acadêmica e científica. Dessa conexão podem surgir potentes processos de transformação social, pois, ao mesmo tempo em que são redes macro, também são microrredes, realizadas nas comunidades, com a identificação e fortalecimento de coletivos com base territorial, sejam no campo ambiental, organização cidadã, cultura e artes, como pontos de cultura, esportes e lazer, comunicação popular, entre outros. Essa combinação entre micro e macro permite uma progressão exponencial dos contatos e afecções entre redes e pontos diversos, cada qual com uma característica, abrindo novos caminhos e alinhavando várias funções, harmonizando cultura com economia, com educação, ambiente, e assim por diante, isso porque é no território que todos esses campos se imbricam. Essa também é uma maneira de abrir novas formas de relacionamento entre Estado e Sociedade, e entre a própria sociedade, tornando essa relação mais equilibrada, em que Sistemas e métodos de gestão (em especial do Estado) devem servir à vida, e não o oposto.

Quando redes e pontos com base territorial local se conectam com outros, em ambientes que intensifiquem a troca horizontal, não em fusão, mas em intersecção, há uma aceleração de processos de desenvolvimento humano. Dessas intersecções são formadas linhas; a partir das linhas, movimento; a partir do movimento, ideias; a partir de ideias, transformações. Quanto mais conexões houver, e originadas nos mais diversos sentidos, mais intenso será o processo, pois as conexões intrarredes funcionam como as sinapses em um cérebro coletivo. Encontrando o "Lugar das Redes" é possível fomentar plataformas de inteligência coletiva, realizadas pela potência de cada um e de todos, em processos de reflexão, encantamento e auto-organização. Foi o que se experimentou com o programa Cultura Viva, sobretudo no Brasil entre 2004/2010, a partir dos Pontos de Cultura.

A base para esse processo de reinvenção coletiva do futuro, por paradoxal que possa parecer, encontra-se nas culturas comunitárias e ancestrais. Isso porque o comunitário e o ancestral se realizam no território e se reproduzem no compartilhamento da memória comum. E não há futuro sem boa raiz. E não há raiz sem território, muito menos sociedade sem memória. O ancestral e o comunitário formam nossas raízes, são raízes vivas, mesmo quando esquecidos 
e abandonados. Tal qual as plantas, sem raiz forte não há crescimento que se sustente. Tal qual as plantas, é das raízes que emana a seiva a alimentar o corpo.

Nos territórios ancestrais e comunitários a vida não está separada da economia, da organização e reprodução social, muito menos da arte. Cultura e vida são ética, estética, educação e economia ao mesmo tempo; e a unidade da vida só é encontrada quando essas quatro dimensões seguem em um mesmo sentido. Em Espinosa, a compreensão do mundo passa pela ética, que consiste em criar condições que aumentam nossa potência e capacidade de agir e pensar. É a ética que nos proporciona o afeto da alegria e nos libera das determinações alheias, afirmando a nossa própria natureza (conatus). Encontrar e praticar a ética (o ambiente da razão, do caráter) só é possível quando ética está intrinsecamente associada à estética (a percepção, a sensibilidade, a sensação). Quando forma e conteúdo se separam, ou quando emoções se separam da razão, os humanos tornam-se seres partidos, perdendo a noção da beleza, caindo no mundo do triste e do feio, do vulgar, e, por que não, do bestial. Para Platão e Aristóteles, o belo, o bom e o verdadeiro, tinham que formar uma unidade. Ao quebrar a unidade, a tristeza, o ódio e o ressentimento, e não a alegria e a justiça, nos comandam, como forças exteriores a nós.

No comunitário e no ancestral, a obtenção e administração dos recursos materiais e humanos está diretamente vinculada aos processos de vida, ao sistema de valores (ética) e à expressão desses valores (estética); do grego "oikos" (casa) e "nomos" (costume, lei). Daí economia, como "regras de administração da casa", que deveria ser comum. Nos tempos atuais, quando o Papa Francisco fala sobre a necessidade da unidade entre as linguagens das mãos, coração e mente, ele também está se referindo à unidade indispensável que deve existir entre ética, estética e economia. Nos processos educativos ancestrais e comunitários, ética, estética e economia são transmitidas e ensinadas em conjunto, por atitudes, em processos de inteireza educativa. Sob o Neoliberalismo, em contraponto, exacerbado em sua dimensão de globalização uniformizadora, as sensações de segurança, proteção e respaldo, necessárias à uma vida equilibrada, são completamente destroçadas, levando as pessoas e as sociedades ao desamparo e, em seguida, ao desespero. Em O mal-estar da civilização, Sigmund Freud (2010 apud SAFATLE, 2013, p. 63) faz a seguinte afirmação:

[...] o ser humano não é uma criatura branda, ávida de amor, que no máximo pode se defender quando atacado, mas sim que ele deve incluir, entre seus dotes instintuais, também um forte quinhão de agressividade. Em consequência disso, para ele, o próximo, não se constitui apenas um possível colaborador e objeto sexual, mas também uma tentação para satisfazer a tendência à agressão, para explorar seu trabalho sem recompensá-lo, para dele se utilizar sexualmente contra sua vontade, para usurpar seu patrimônio, para 
humilhá-lo, para infligir-lhe dor, para tortura-lo e mata-lo. 'Homo homini lúpus [O homem é o lobo do homem].

Nos tempos presentes essa afirmação se revela às escâncaras e o Neoliberalismo também poderia ser definido como uma sociopatia globalizada. Um mundo em que a razão é não ter limites, tornando a exploração de tudo e de todos a meta principal. Uma sociedade doente vivendo em anomia. Sociedades doentes são aquelas em que ética, estética, economia e educação caminham em direções diferentes. Um exemplo de doença social seriam as sociedades homicidas. O Brasil é um país que pode ser classificado como uma sociedade homicida (30 homicídios por 100 mil habitantes, ou 63.500 assassinatos em 2017) conforme os dados apresentados pelo OP9: O Portal do Sistema Opinião (2019). Em países com essa característica, como Brasil, também Colômbia e Triângulo Norte da América Central (Honduras, El Salvador e Guatemala), a culpa sempre é remetida ao "outro", com as pessoas desresponsabilizando-se pelo bem-estar do coletivo; em meio à iniquidade, a vida é banalizada e as raízes ancestrais e comunitárias vão sendo esgarçadas. O reverso dessa características entre povos e nações, ou o reverso da moeda, também em doença social, seria o Japão (18,5 suicídios por 100 mil habitantes, ou 25.000 suicídios em 2015) conforme a BBC News Brasil (2015); em países suicidas a característica seria atribuir sempre ao indivíduo, a responsabilidade pelos fracassos e erros, gerando um forte sentimento de que a cultua é sempre a da própria pessoa, e a honra vale mais que a vida. A sociopatia do Neoliberalismo seria junção dessas duas doenças, desresponsabilização pelo bem-estar coletivo, por um lado, e auto-culpabilidade, por outro, deixando as pessoas ainda mais desamparadas e sujeitas à manipulação.

Em um mundo globalizado e uniformizado, fortemente marcado pelos princípios do Neoliberalismo, exacerbando os valores da ambição, ganância, egoísmo, a desregulamentação dos processos de mediação entre vida e Sistemas históricos surge como uma necessidade intrínseca do próprio Sistema. Vale a "lei do mais forte", da acumulação infinita, passando por cima de tudo e todos, padronizando relações sociais, descartando pessoas e modos de vida, dirigindo e direcionando afetos, sensações, sentimentos e desejos, com o objetivo de coisificar e mercantilizar a vida. Atribui-se às pessoas, e não ao processo social, a "culpa", pelos êxitos e fracassos de cada um. É essa combinação de doenças sociais que prepara terreno para o que Noam Chomsky define como "Volta à granja", desviando a atenção do público em relação aos problemas que realmente importam à sua vida.

Como reflexo, assistimos à vulgarização e mediocrização da cultura e das artes; a cultura do descartável, do imediato, do vulgar. Os Sistemas educativo, de comunicações, e religiões fundamentalistas, agem para projetar esses valores tristes à enésima potência. Escolas se 
vangloriando de formarem para o Mercado. Um Mercado em que o valor maior é a desigualdade, o egoísmo, a acumulação infinita, baseadas no desprezo e no descarte. Igrejas manipulando a fé, pregando a teologia do individualismo e da prosperidade egoísta, da ostentação. Uma política do ódio. Tudo isso resulta em uma vida social idiotizada, ridicularizando singularidades e modos de viver em 'outros mundos". Uma existência banal, fazendo com que a própria vida perca sua dignidade. E um gradual e contínuo processo de infantilização da vida social, a partir da manipulação de emoções, levando as pessoas a comportamentos próximos à debilidade, destroçando o "sentido crítico dos indivíduos", mantendo-os na ignorância e mediocridade, em que a "moda é o ato de ser estúpido, vulgar e inculto", conforme aponta Chomsky, ao descrever as dez estratégias de manipulação em massa.

O transtorno psíquico do Neoliberalismo resulta da absoluta incoerência e separação entre mãos, coração e mente, cada qual apontando para um lado. Um mundo regido por valores que fazem com que indivíduos e sociedades não ajam pelo que sentem, muito menos pelo que refletem, racionalmente e na esfera do sensível. Um mundo governado pelo egocentrismo exacerbado, fruto de um individualismo cultivado como valor absoluto, em que "Consumo" é ideologia. E ganância, hedonismo e imediatismo, os meios para realizar a ideologia. É a partir desses valores que o Neoliberalismo se impõe aos demais sistemas humanos. Do mesmo modo que um sociopata, o Neoliberal desconsidera leis, normas sociais e direitos de outras pessoas, de comunidades, países, do planeta e seus diversos seres; não tem sentimento de responsabilidade para com os outros, e glorifica essa falta de sentimento, bem como glorifica a estupidez e expressa um comportamento violento, seja na expropriação de meios de vida, seja na prática explícita da violência como meio para atingir seus objetivos.

Nas sociedades dominadas pelo Neoliberalismo, o medo é o afeto político central. De um lado, esse medo pode levar à demanda desesperada pela personificação da autoridade, buscando personagens idealizados, trazendo por resultado a constituição de horripilantes processos de imposição do Poder Absoluto. De outro, segundo Safatle (2013), pode desencadear processos de despossessão em meio ao desamparo. Citando Judith Butler (2004), o filósofo aponta que as pessoas e sociedades, ao serem despossuídas por outras, passam por um processo de interrupção da narrativa autoconsciente que elas tinham sobre si mesmas, mudando a própria noção de sua existência, como agentes autônomos e providos de controle. Diz Judith Butler: 
mas pode e revela uma base da relacionalidade - não apenas nos movemos, mas somos movidos por aquilo que está fora de nós, por outros, mas também por algo 'fora' que reside em nós” (SAFATLE, 2013, p. 75).

Partindo desse pensamento, Safatle conclui:

[...] ligar-se a outros não é apenas confirmar-se em suas predicações supostas, mas é estar em contínua despossessão por ter algo fundamental de mim em um outro que não controlo, que não saberei como responderá ou se responderá. Por isso, a relacionalidade própria à condição humana não pode ser compreendida como garantia de cooperação. Que a despossessão possa aparecer também como expressão máxima de uma vulnerabilidade produzida pela insegurança social e civil a ser politicamente combatida com todas nossas forças, já que produção de um não ser social. Isso não elimina a necessidade de uma política capaz de quebrar a substancialização do 'individualismo possessivo', através da afirmação da produtividade de situações de insegurança ontológicas formas de despossessão ligadas à insegurança social e civil são modos de sujeição. Já aquelas vinculadas à insegurança ontológica são modos de liberação (SAFATLE, 2013, p. 75-76).

O contraponto mais vigoroso à Sociopatia Neoliberal está, justamente, nos grupos comunitários e ancestrais, pois vivendo sob a ética da responsabilidade. A ética da responsabilidade, e da reciprocidade, resultaria em sociedades saudáveis e está presente nas franjas do mundo capitalista, cabendo religar e reinventar processos de vida nas sociedades contemporâneas com a ancestralidade e o comunitário. Inclusive porque esses sobrevivem e resistem nas bordas do sistema capitalista.

A busca por sociedades saudáveis depende, em primeiro lugar, da compreensão de como a civilização humana chegou a esse estágio, com adequado diagnóstico de causa e efeito, que pressupõe profundidade analítica e, sobretudo, inteireza ética, estética, econômica e educativa. Uma das ferramentas que pode nos propiciar essa inteireza é a Cultura do Encontro $^{2}$, a partir de processos empáticos, realizados no exercício da alteridade. Quando a Cultura do Encontro se "encontra" com a Cultura Viva Comunitária ${ }^{3}$, a raiz ancestral flui, fazendo florescer uma árvore frondosa.

\footnotetext{
${ }^{2}$ CULTURA DO ENCONTRO - conceito desenvolvido por Jorge Bergoglio, Papa Francisco, que pressupõe o encontro das três linguagens do ser: coração, mente e mãos. Expressa na ideia do sentir-pensar-agir e realizada a partir da integração e diversidade entre indivíduos e coletividades, rompendo com a fragmentação e buscando a 'Unidade'. É o estímulo ao encontro entre os diferentes, buscando a unidade na diversidade, por uma globalização poliédrica e não esférica, uniformizante.

${ }^{3}$ CULTURA VIVA COMUNITÁRIA - Movimento Continental Latino Americano, formado a partir da experiência brasileira com o programa CULTURA VIVA. Pressupõe o fortalecimento e potencialização de culturas em interação entre processos de invenção e tradição, com grupos de base comunitária e coletivos de vanguardas artísticas ou de tecnologias digitais. Expressa no tripé autonomia-protagonismo-empoderamento sociocultural, acelerando processos de desenvolvimento em rede, a partir de Pontos de Cultura.
} 
Das culturas comunitárias e ancestrais brota a seiva a alimentar e energizar a Cultura do Encontro. Isso porque as relações comunitárias se sedimentam no comum, na repartição de território e memória, na comunhão da vida, entre os humanos e, destes, com os demais seres. Não se trata de romantizar ou idealizar o comunitário e o ancestral, ao contrário. O comunitário e o ancestral interagem, em diferentes medidas, com os outros Sistemas, e são afetados por esses, como também podem afetar e alterar o funcionamento e a lógica desses Sistemas. Tradições podem remeter à imobilidade e anacronismo, reproduzindo um passado imobilizado, reacionário até; isso quando agarrados a relações fixas de poder e às ideologias hegemônicas. Partindo de uma perspectiva decolonial, as tradições podem detonar processos de potência e resistência. É um equívoco considerar as tradições apenas como uma repetição do passado; e, no caso dos países coloniais, fincadas em relações coloniais de poder. Ao reencenar o passado em linguagens performáticas, utilizando o conjunto dos sentidos, incluindo a razão, as tradições também se reinventam. Elas próprias foram inventadas um dia. Se as tradições podem se conformar, também podem se transformar, do mesmo modo que valores e costumes se modificam. Conforme Eric Hobsbawm (1991, p. 56):

A 'tradição', nesse sentido, deve ser nitidamente diferenciada do 'costume', vigente nas sociedades ditas 'tradicionais'. O objetivo e a característica das 'tradições', inclusive das inventadas, é a invariabilidade. O passado real ou forjado a que elas se referem impõe práticas fixas (normalmente formalizadas), tais como a repetição. O 'costume', nas sociedades tradicionais, tem a dupla função de motor e volante. Não impede as inovações e pode mudar até certo ponto, embora evidentemente seja tolhido pela exigência de que deve parecer compatível ou idêntico ao precedente. Sua função é dar a qualquer mudança desejada (ou resistência à inovação) à sanção do precedente, continuidade histórica e direitos naturais, conforme expresso na história.

O comunitário e o ancestral remetem diretamente à tradição; do latim, "Traditio", entregar, ou "tradere", passar adiante. Nesse sentido, a tradição é o vaso comunicante entre permanência e mudança, em que passado-presente precisam ser percebidos em uma perspectiva dinâmica. Pela tradição ancestral tudo está relacionado, conectado, em uma totalidade. Somos "poeira do universo", a física já demonstrou; ou "sopro de Deus", conforme diversas religiões e mitos ancestrais. Compreendendo essa dimensão, presente no tradicional comunitário, ou nas culturas tradicionais, será possível reencontrar o "fio de Ariadne"4, a nos levar para fora do labirinto de um mundo desencontrado, partido em meio à despossessão.

\footnotetext{
${ }^{4}$ Do mito de Teseu e o Minotauro, na Ilha de Creta, em fase pré-helênica, há, ao menos, trê milênios. Sem que Ariadne adentrasse no Labirinto desfazendo suas vestes, de modo a garantir um fio contínuo que, na volta, pudesse
} 
Pela tradição é possível recuperar conceitos, éticas, filosofias, modos de vida e de interpretação do mundo de povos e modos de vida não hegemônicos. Seria um seguir pegadas, da frente para trás, mas apontando ao futuro; um exercício de historicidade que significaria:

[...] o conhecimento sobre o passado como um meio de romper com ele - ou, ao menos, manter apenas o que pode ser justificado de uma maneira proba. A historicidade, na verdade, nos orienta primeiramente para o futuro. O futuro é visto como essencialmente aberto, embora como contrafatualmente condicional sobre linhas de ação assumidas com possibilidades futuras em mente (GIDDENS, 1991, p. 56).

Esses modos de ser, de pensar e agir, estão guardados no fundo escondido de nossas almas. Por vezes nem sabemos exatamente de onde vieram, como no caso de brincadeiras infantis, mas seguem bem guardados em nosso "baú da memória", ou DNA ancestral. Os modernistas brasileiros já haviam percebido isso, tanto nas dimensões éticas e estéticas, expressas em seus processos criativo/inventivos. É neste ponto que a cultura comunitária oferece a sua mais significativa contribuição: o elemento lúdico, o jogo e a brincadeira, que estão integrados a todos os processos da vida e da própria reprodução social e transmissão de conhecimentos e sentidos. Em Homo Ludens, o filósofo Huizinga (2001, p. 85) identifica que:

[...] nosso ponto de partida deve ser a concepção de um sentido lúdico de natureza quase infantil, exprimindo-se em muitas e variadas formas de jogo, algumas delas sérias e outras de caráter mais ligeiro, mas todas elas profundamente enraizadas no ritual e dotadas de uma capacidade criadora de cultura, devido ao fato de permitirem que se desenvolvessem, em toda sua plenitude, as necessidades humanas inatas de ritmo, harmonia, mudança, alternância, contraste, clímax, etc. Esse sentido lúdico está inseparavelmente ligado a um espírito que aspira à honra, à dignidade e à beleza. Tanto a magia, como o mistério, os sonhos de heró́smo, os primeiros passos da música, da escultura e da lógica, todos esses elementos da cultura procuram expressão em nobres formas lúdicas.

Imbricando o lúdico com a própria vida, os ambientes comunitário e ancestral exercitam sensações e se autodesafiam, correm riscos, suportam a tensão e a incerteza. E convertem esse processo em um jogo permanente, fazendo que vida cotidiana, séria, por assim dizer, 'jogue' em ambientes de tensão e alegria, tornando-se um eficaz meio de coesão e reprodução social. O historiador e crítico literário, Nicolau Sevcenko (1992), estudou o furor inventivo sob o qual vivia a cidade de São Paulo na década de 1920, absorta pelo impacto das novas tecnologias em

indicar o caminho de saída, Teseu, mesmo vencendo o Minotauro, jamais teria conseguido sair do Labirinto. $\mathrm{O}$ fio de Ariadne é o fio da tradição, do caminho seguro da volta. 
seu momento de metropolização; ele faz a seguinte análise sobre a obra de Mário de Andrade, um dos grandes pensadores e poetas do Modernismo:

Mário de Andrade já tinha àquela altura o seu 'Paulicéia desvairada' pronto para publicação naquele mesmo ano. Seus poemas primavam pela ironia, ora fina, ora beirando o sarcasmo, com a qual fustigava algumas das mais torpes fontes do mal-estar da cidade. Travestido de arlequim, o poeta musicava o seu verso, agitava o ritmo e, num clima de animação eufórica, sem tirar a máscara, evocava as vítimas e indigitava os malfazentes. O tom de canto e dança varia, com alguns versos sublimes, imagens soltas, notas plangentes, cortes bruscos, recorrências, crispações, risos e cutiladas, o poeta referendava para melhor desancar, a própria mobilização aceleradora e artificial da sociedade paulista. (SEVCENKO, 1992, p. 271)

O mal-estar na civilização contemporânea é fruto de jogos no cotidiano, como expressos na obra de Mário de Andrade, que buscava compreender e responder a esse mal-estar com sua poesia performática. Como pensador do Brasil, "travestia-se de arlequim”, produzindo uma obra literária em movimento, apontando para o futuro, a partir de críticas do presente. Mas ele ia além, e cavoucava até o fundo da raiz performática da cultura popular. Somos indivíduos partidos, em avançado processo de coisificação. Isso resulta em sociedades partidas e coisificadas, e em avançado processo de uniformização, de apagamento do singular, das peculiaridades, fazendo com que a dignidade própria dos indivíduos, das formas de vida e das sociedades, vá desaparecendo. O Modernismo reestabelecer um sentido de unidade a partir do popular, do profundo e ancestral. Quando percebemos que não estamos sós, quando compartimos sensações, emoções e sentidos, quando reconhecemos solidariedade, principalmente de pessoas desconhecidas, nos revigoramos e nos ressignificamos. Esses revigoramentos e ressignificações se alimentam do comunitário que está escondido no fundo de nossa alma, e dos valores ancestrais, tal qual "sementes de trigo que, durante milhares de anos, ficaram fechadas hermeticamente nas câmaras das pirâmides, e que conservam até hoje suas forças germinativas" (BENJAMIN, 1985, p. 204).

O resgate e ressignificação dos valores ancestrais passa por compreender a dimensão da Performance como elemento essencial para a construção do pensamento e do universo narrativo. Performance remete à prática da enunciação, em que a linguagem se apresenta não apenas em sua forma racionalizada, sistematizada na escrita, mas como uma ferramenta viva, por isso, instável. A linguagem performática mistura em uma só narrativa um conjunto de expressões, como música, dança, memoração, causos, lembranças, aforismos. Essa multiplicidade de meios de expressão e gêneros textuais, ao contrário do que uma visão colonizadora do conhecimento tenta impor, enriquece a narrativa, exatamente por dispor de 
várias formas de inteligência, e por interagir com o público. Ela jamais é estática. É essa dinâmica capacidade de troca, entre narrador e ouvinte, invertendo papeis na própria narração, que dá potência transformadora ao "Ser Comunitário" e às culturas tradicionais. Ela insere à narrativa processos de disputa e crítica, de transgressão e ruptura.

Na América Latina, sobretudo na América andina, essa ressignificação acontece pelo resgate do Sumak Kawsai, do povo Quéchua; ou Suma Qamaña, dos Aymara; ou Teko Porã, dos Guarani, o povo das terras baixas. São práticas milenares e que possibilitaram uma profunda conexão entre as sociedades humanas e os demais seres que habitam o Planeta. Do Sumak Kawsai nasce o conceito do Bem Viver. Mais que um conceito, um modo de vida que nos abre a oportunidade para imaginar novos mundos. O Teko Porã dos Guarani significa "um modo bom de viver em comunidade”. Teko, casa, ou, mais precisamente, vida em comunidade; Porã, o belo, o bonito, o bom.

Esse conceito está presente também no modo de ser dos povos indígenas na floresta amazônica. Em civilizações florestais, ou melhor, nesses jardins florestais, nessas florestazações, se comparte a ideia de que o mundo é povoado de seres, e que todos esses seres são dotados de consciência, cada qual percebendo a si mesmo, e às outras espécies, a partir de sua perspectiva; no que o antropólogo brasileiro, Eduardo Viveiros de Castro, conceituou como "Perspectivismo Xinguano", o modo dos indígenas amazônicos de perceber e conceber a realidade. Esse entendimento de que todos os seres são dotados de sentido percorre as Américas, da Terra do Fogo ao Alaska, dos Mapuche aos Inuits. E ultrapassa continentes, está presente nas vivências com Dersu Uzalá, na Sibéria, com os povos polinésios, os bosquímanos na África, os celtas na Europa. Tudo na vida tem sentido, de um grão de areia às formas de vida mais complexas, é o que os povos ancestrais têm a nos ensinar.

A contemporânea proposta do Bem Viver, aplicada na Constituição de países como Bolívia e Equador, com o reconhecimento dos direitos da Pachamama, não encara a Mãe Terra, ou a Natureza, como um cesto de recursos a serem explorados, mas como uma Comunidade da Vida, em que todos os seres precisam ser reconhecidos como sujeitos de direitos. A base para esse reconhecimento está na ideia de que se tudo na vida tem sentido; como tal, os seres são dotados de dignidade própria, devendo serem respeitados e sacralizados, isso porque a vida é sagrada. É o oposto do antropocentrismo.

Nas sociedades capitalistas, de tão colonizadas, de tão formatadas em processos de educação que negam outras formas de inteligência e percepção, sobretudo na dimensão do sensível, não se admite essa hipótese, assim como não se admite que povos ancestrais pudessem produzir filosofia, ética e modos de vida refinados, por não dotados da escrita conforme 
conhecemos. Praticamente nega-se a esses povos o reconhecimento à filosofia, sob a justificativa de que não sistematizadas e racionalizadas, porque transmitidas pela oralidade e fundadas em métodos outros de inteligência e observação, que não os da ciência stricto sensu.

Essa reinvenção do futuro a partir do resgate de filosofias ancestrais, como no caso do Bem Viver, acontece não somente com o pensamento ancestral ameríndio e comunitário. Há outras expressões da filosofia e da ética ancestral, que também se reinventam, em intensa pulsação. A Permacultura, a cultura da permanência, baseada no modo de vida dos aborígenes da Austrália. Também a ética e a filosofia Ubuntu, aplicada por Nelson Mandela e Desmond Tutu no processo de superação do apartheid na África do Sul. Esses modos de pensar, de ser e agir, revelam toda uma vitalidade, que permitiu a realização de civilizações em convívio com a natureza, por milhares de anos.

Atualmente, o grande desafio da civilização humana é romper com o antropocentrismo. Não se trata de um imperativo ético-filosófico, apenas, mas da própria existência, porque, se o antropoceno não for modificado há tempo, levará a humanidade à autodestruição. O Planeta poderá seguir independente de nós, mas com um ecossistema bastante alterado e aviltado, exatamente por reflexo da intervenção humana, desmensurada em sua ambição e prepotência. Mesmo em caso de sobrevivência da espécie humana, talvez convivendo com a espécie póshumana, o resultado poderá ser aterrador, em meio a ambientes de barbárie, desolação e desigualdade nunca dantes imaginados. É imperativo, ou começamos a praticar outros modos de vida, mais biocêntricos e plurais, ou sucumbiremos em meio a uma ética da exploração e do descarte, de tudo e de todos. Superar o antropoceno e o modo de produção capitalista e produtivista (também socialista, quando reproduzindo os mesmos vícios intrínsecos ao capitalismo, a partir da lógica produtivista, em que a exploração não tem limites) é condição indispensável para a recuperação da dignidade própria da vida.

Bem Viver não é uma alternativa de desenvolvimento e sim uma alternativa ao desenvolvimento, tal qual o mundo ocidental conceituou a ideia de desenvolvimento. Seria muito mais um 'Re-envolver', um Conviver, do que um Des-envolver, de separar, segregar. Enquanto o Des-envolver separa os humanos de sua condição de natureza, o Bem Viver junta, une, religa, harmoniza. Uma harmonia que se estabelece em três dimensões: do indivíduo com ele mesmo; do indivíduo com a coletividade humana; da coletividade humana com os demais seres. É uma ética e uma filosofia que se afirmam no equilíbrio, na harmonia e na convivência entre os seres. Cultura Viva como Bem Viver envolve uma profunda conexão e interdependência com a natureza, na vida em pequena escala, sustentável e equilibrada, tendo por fundamento o fortalecimento de relações de produção autônomas e autossuficientes. 
Também se expressa na articulação política da vida, em práticas construídas em espaços comuns de socialização, coletivos culturais e artísticos, jogos, brincadeiras e manifestações em parques, jardins, teatros, museus, bibliotecas, hortas urbanas ou palácios. Independe o local ou a estrutura, porque a vida é intangível e se espraia em abundância, acontecendo em tudo e todos.

É um modo "Performático" de vida social e política, integrando racionalidade com emoção. Uma experiência vivida, ou simplesmente, "vivência", conforme o antropólogo Victor Turner (2005) conceitua. Essa experiência, a partir da narrativa performática é constituída por cinco momentos: a) percepção, resultando em sensação de dor ou prazer, de êxtase e maravilhamento; b) evocação a referências passadas, via imagens de linguagem; c) emoções revividas, associadas às referências passadas; d) o sentido narrativo da conexão entre passado e presente; e) a experiência como resultado da expressão performática intensa. É a Performance como processo, que só se realiza plenamente nas culturas tradicionais e comunitárias. Um ato narrativo que "realiza" a experiência. Uma forma intensa de transmutar a percepção do "Eu" a partir da observação do "Outro".

Como apontado por John Dewey (2010), "toda cultura tem sua individualidade coletiva”. O Bem Viver é, ao mesmo tempo, um modo de vida, alicerçado em práticas ancestrais, como uma filosofia e uma ética de futuro, aplicada na contemporaneidade. Uma ideologia da práxis ancestral, oferecida como ética de vanguarda àqueles que querem tentar, se aventurar, se arriscar. É também uma epistemologia do Sul, composta em forma narrativa a evocar a experiência de povos insubmissos. Walter Benjamin (1985) chama atenção para processos de apagamento da memória, de esquecimento, vividos nas experiências contemporânea. Ele retoma à tessitura narrativa, encontrada na Grécia Antiga, não referindo-se aos fios de Ariadne, mas ao tapete de Penélope, que à noite ela desfaz o que teceu durante o dia. Em “O Narrador", Benjamin demonstra que a tradição oral decorre da poesia épica:

[...] somos pobres em histórias surpreendentes. A razão é que os fatos já nos chegam acompanhados de explicações. Em outras palavras: quase nada do que acontece está a serviço da narrativa, e quase tudo está a serviço da informação. Metade da arte narrativa está em evitar explicações. [...] O extraordinário e o miraculoso são narrados com a maior exatidão, mas o contexto psicológico da ação não é imposto ao leitor. Ele é livre para interpretar a história como quiser, e com isso o episódio narrado atinge uma amplitude que não existe na informação. (BENJAMIN, 1985, p. 203)

O encantamento, a partir da contemporaneidade, com o Ancestral e o Comunitário reside exatamente nesse toque mágico, fazendo com que o expectador/leitor/participante perceba a realidade de uma forma diferente, estando livre a "interpretar a história como quiser", e, a partir 
daí, sentindo-se convidado a entrar na história como sujeito. Benjamin (1985, p. 205) enfatiza que, "Contar histórias sempre foi a arte de contá-las de novo, e ela se perde quando as histórias não são mais conservadas. Ela se perde porque ninguém mais fia ou tece enquanto ouve a história."

Cultura Viva, não consiste em "uma volta ao passado", aprisionando-se em uma ancestralidade imutável, reproduzida em estética contemporânea; assim como não se deve confundir Bem Viver com o "Viver Melhor" capitalista, sustentado na exploração máxima dos recursos disponíveis, até que as fontes básicas da vida sejam exauridas. Desse encontro entre Cultura Viva e Bem Viver busca-se uma vida mais justa, que se contraponha à iniquidade própria do capitalismo, em que apenas poucos podem viver bem, em detrimento da grande maioria, e as narrativas são dominadas por ainda mais poucos. É um encontro criativo, solidário, sustentável. Vivo porque dinâmico, o oposto de uma cultura mercantil, coisificada, tornada Cultura Morta, porque coisa, da mesma forma que uma mesa de madeira é árvore morta. O Bem Viver e a Cultura Viva também pressupõem o direito de amar e ser amado, com o florescimento saudável de todos os seres e o prolongamento indefinido das culturas, a sua recriação e intersecção; o tempo livre para a contemplação, a ampliação das liberdades, capacidades e potencialidades de todos e de cada um. É a cultura da alegria, da amorosidade e da potência. É a economia da partilha, da reciprocidade e do cuidado. É a política da vida.

O Bem Viver tem sido praticado há milênios pelos povos originários desse vasto continente que veio a ser chamado de América. De há poucas décadas, começa a ser estudado, sistematizado e conceituado, por teóricos e acadêmicos, sobretudo nas universidades andinas de Quito e La Paz, e em Assunção, no Paraguai. Entre as principais referências, o economista equatoriano, Alberto Acosta, que também foi presidente da Assembleia Constituinte do Equador, a Assembleia de Montecrist, de 2007, fazendo com que o Equador fosse o primeiro país do mundo a incorporar os direitos da natureza como um sujeito de direitos (posteriormente a Bolívia também absorveu os direitos da Pachamama em sua Constituição). Essa é uma ideia totalmente diferente da lógica da preservação ambiente existentes nos países ocidentais. Esses, mesmo quando incorporam a necessidade da defesa do ambiente, seguem raciocinando a partir da mesma lógica, de que o ambiente deve ser preservado para servir aos humanos, e não por sua dignidade própria. Para o Bem Viver, as águas tem direito a seguirem seu curso, assim como são dotadas de inteligência, e devem ser respeitadas em sua pureza, sendo preservadas da imundície e putrefação; os Bosques são fontes de vidas, sistemas em que outros sistemas coabitam, e devem ser respeitados como tal, da mesma forma que as montanhas, as pedras, os 
animais e plantas. Essas ações e reflexões tem elevado o Bem Viver a um outro patamar de reconhecimento e legitimidade.

O Bem Viver, como alternativa ao desenvolvimento, é uma proposta civilizatória que reconfigura um horizonte de superação do capitalismo. Isso não significa - como disse Mônica Chuji, indígena e ex-deputada constituinte de Mantecrist - 'um retorno ao passado, à idade da pedra ou à época das cavernas', e tampouco uma negação à tecnologia ou ao saber moderno, "como argumentam os promotores do capitalismo". José María Tortosa vai além, ao sintetizar que 'o Bem Viver é uma oportunidade para construir outra sociedade, sustentada em uma convivência cidadã em diversidade e harmonia com a Natureza, a partir do conhecimento dos diversos povos culturais existentes no país e no mundo'. E isso significa, conclui o sociólogo português Boaventura de Souza Santos, que o Bem Viver é "um conceito de comunidade onde ninguém pode ganhar se seu vizinho não ganha. A concepção capitalista é exatamente oposta: para que eu ganhe, o resto do mundo tem que perder (ACOSTA, 2015, p. 76).

Ao se aproximar do Bem Viver ameríndio, a Cultura Viva e Comunitária também se aproxima da ética e da filosofia ancestral africana. Ubuntu: "eu sou porque nós somos”, ou "força em movimento"; do banto: Ubu, força, Untu, movimento. Para o Ubuntu, viver em comunidade é romper com o individualismo, resgatando a sensação de pertencimento à unidade na diversidade. O resgate dessa filosofia tradicional africana coloca a emancipação e a cidadania em novos patamares, fazendo com que a interdependência e a colaboração, intra e entre comunidades, se realizem em processos de diálogo, consenso, inclusão, compreensão, compaixão, partilha, cuidado e solidariedade. A humanidade de todos e de cada um está indissoluvelmente ligada à humanidade dos outros, essa é a síntese do Ubuntu. No comunitário os encontros precisam ser festivos, acolhedores, generosos, performáticos, assim as comunidades se fazem fortes, potentes, resilientes. Não há como praticar a filosofia Ubuntu sem estar aberto e disponível aos outros, e é com essa atitude que a pessoa não se sentirá intimidada, ganhando coragem e autoconfiança para se colocar no mundo. Para a ética Ubuntu jamais é possível que uma pessoa esteja bem se o entorno dela não estiver bem. Segundo Desmond Tutu (1999):

A minha humanidade está presa e está indissoluvelmente ligada à sua. Eu sou humano porque eu pertenço. Ele fala sobre a totalidade, sobre a compaixão. Uma pessoa com ubuntu é acolhedora, hospitaleira, generosa, disposta a compartilhar. A qualidade dá às pessoas resiliência, permitindo a elas sobreviver e emergir humanas, apesar de todos os esforços para desumanizálas. Uma pessoa com ubuntu está aberta e disponível aos outros, assegurada pelos outros, não se sente intimidada pelos outros serem capazes e bons, para ele ou ela ter autoconfiança, que vem do conhecimento de que ele ou ela tem do seu próprio lugar no grande todo. 
Uma filosofia ancestral que se espalhou por toda a África, tratando dos mesmos valores de compaixão, partilha, totalidade, expressos em muitas outras filosofias e religiões, e que tem muito a nos ensinar.

A aproximação entre as Cultura do Encontro e Cultura Viva Comunitária, e dessas com as filosofias do Bem Viver e Ubuntu, promove a descolonização de mentes e corpos, fazendo com que o refletir e o sentir assumam um sentido único. É uma outra perspectiva filosófica, que faz com que a ética e a filosofia de povos, antes desprezados em suas formas de conhecimento, sejam valorizadas em plenitude. Uma filosofia que se transforma em práxis, seja nos momentos de reflexão, contemplação, ou na prática cotidiana, por isso racional e emocional ao mesmo tempo.

\section{CONSIDERAÇÕES FINAIS}

Quando expressões do comunitário e o ancestral são praticadas, os encontros ganham energia, assumem formas circulares, espiraladas. Em meio às rodas, às peñas e cirandas, com muita festa, em que todos se olham sem hierarquias, a Cultura Viva mistura a tudo isso, fazendo com que jovens da cultura digital se encontrem com grupos de cultura tradicional; que a arte experimental e de vanguarda se reinvente nas ruas, e com a cultura de rua; são povos indígenas a campesinos, de favelas e quebradas, e de universidades, de teatros de vizinhos aos teatros nacionais, de grandes museus a museus de vizinhança, de bibliotecas comunitárias a grandes bibliotecas. Tudo cabe na Cultura Viva, desde que o objetivo seja a Cultura do Encontro, quebrando hierarquias culturais e construindo novas legitimidades. Tudo cabe na Cultura Viva porque, quando a cultura é viva, ela se reinventa todo dia e não tem medo do contato com o diferente.

Pelas Cultura Viva e a Cultura do Encontro, temos a oportunidade de quebrar hierarquias culturais de dominação, semeando novas legitimidades, agora ombreadas entre o ancestral, o comunitário, o cosmopolita, o urbano, o popular, o erudito, o escrito, o oral, o acadêmico, o das instituições, o das ruas, o das pessoas, o das identidades, o das sociedades, a permanência e a ruptura. O objetivo? Um novo padrão civilizatório. Nada menos que isso. Um mundo com economia circular e solidária, compartilhada, sustentável, em processos de comércio justo, consumo consciente e trabalho colaborativo, com novos padrões de democracia e partilha de poder, de criatividade e invenção, de reciprocidade, de compaixão, de dádiva. É um outro mundo possível, e ele é possível para já. Um mundo em que caibam outros mundos, como dizem os zapatistas. 
É possível conviver. É possível ter menos para que todos tenham o suficiente, e que todos possam viver bem, em ambientes de equidade, fazendo prevalecer a reciprocidade, o respeito, a responsabilidade, a convivência, o dispor no lugar do impor. Cultura do Encontro é cultura de paz e convivência, é cultura que se fortalece nas diferenças, o traz o diferente para perto, escuta com sensibilidade, com o coração ao lado da razão. Cultura Viva Comunitária é aprender com o "Ser Comunitário", com as sabedorias ancestrais, e, ao lado delas, junto com elas, nos ofertar a seiva para o salto civilizatório de que o mundo tanto necessita. O mais incrível é que tudo isso já está acontecendo, no exato momento desta leitura, sobretudo nos rincões mais olvidados de nossa América Latina. O desafio, agora, é que a Academia, ou melhor, as Academias, as Universidades, os intelectuais, se somem a esse profícuo processo já em andamento. Não para ensinar, nem tampouco para apenas aprender, mas para fazer junto, em um mundo novo. Um sentir-pensar-agir que nasce na terra e da terra outrora conhecida como o Novo Mundo.

\section{REFERENCIAS}

ACOSTA, Alberto. O Bem Viver. Tradução Tadeu Breda. São Paulo: Ed. Autonomia Literária; Elefante, 2015.

BAIRON, Sérgio. Texturas Sonoras: aúdio na hipermídia. São Paulo: Ed. Hacker, 2005.

BENJAMIN, Walter. Obras Escolhidas: Magia e Técnica, Arte e Política. São Paulo: Brasiliense, 1985. (O NARRADOR).

BUTLER, Judith. Precarius Life: The power of mourning and violence. Londres: Verso, 2004.

BBC NEWS BRASIL. Por que o Japão tem uma taxa de suicídios tão alta? 5 jun. 2015. Disponível em: https://www.bbc.com/portuguese/noticias/2015/07/150705_japao_suicidio_rb

DEWEY, John. Arte como Experiência. São Paulo: Martins Fontes, 2010.

FREUD, Sigmund. O mal-estar na civilização. São Paulo: Companhia das Letras, 2010.

GIDDENS, Anthony. As consequências da modernidade. São Paulo: Ed. UNESP. 1991.

GIDDENS, Anthony. Modernidade e Identidade. Rio de Janeiro: Zahar, 2002.

HOBSBAWM, Eric. A invenção das tradições. Rio de Janeiro: Paz e Terra, 1984.

HUIZINGA, Johan. Homo Ludens. São Paulo: Ed. Perspectiva, 2001

OP9: O Portal do Sistema Opinião. Brasil teve 63.880 assassinatos em 2017. Foram 175 mortes por dia. 17 jan. 2019. Disponível em: https://www.op9.com.br/br/noticias/brasil-teve63-880-assassinatos-em-2017-foram-175-mortes-por-dia/. 
SAFATLE, Vladimir. O circuito dos afetos: Corpos políticos, desamparo e o fim do indivíduo. São Paulo: Autêntica, 2013.

SEVCENCO, Nicolau. Orfeu Extático na Metrópole: São Paulo sociedade e cultura nos frementes anos 20. Rio de Janeiro: Companhia das Letras, 1992.

THOMPSON, E. P. Costumes em comum: estudos sobre cultura popular tradicional. Rio de Janeiro: Companhia das Letras, 1998.

TURINO, Célio. Ponto de cultura: o Brasil de baixo para cima. São Paulo: Anita Garibaldi, 2009.

TURNER, Victor. Floresta de símbolos: aspectos do ritual Ndembu. Niterói: Editora Universidade Federal Fluminense, 2005.

TUTU, Desmond. No Future without forgiveness. Doudleday Ed., Nova York, 1999. 